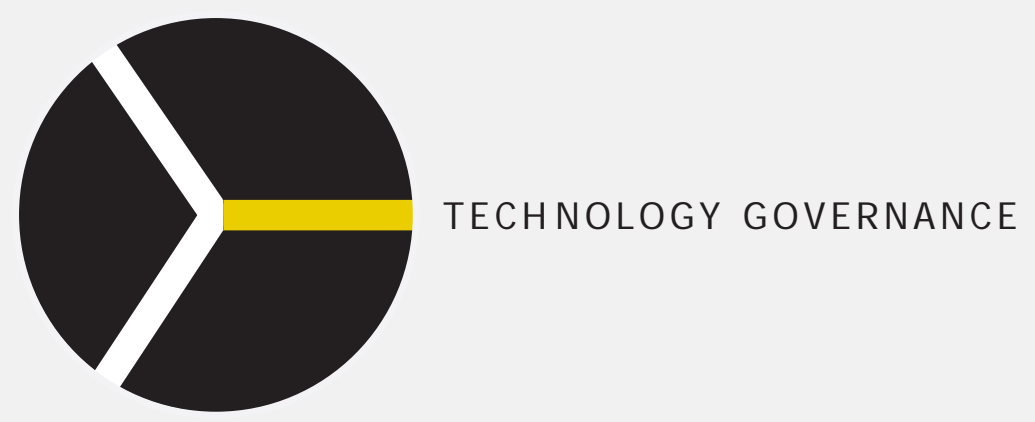

\title{
The Relevance of Ragnar Nurkse and Classical Development Economics
}

Rainer Kattel, Jan A. Kregel, Erik S. Reinert

Forthcoming in 'Ragnar Nurkse (1907-2007): Classical Development Economics and its Relevance for Today', Rainer Kattel, Jan A Kregel and Erik S Reinert, eds., The Anthem Other Canon Series, Anthem: London, 2009.

March 2009

Every larger undertaking, whenever it unites continuously a certain number of men for a common economic purpose, reveals itself as a moral community.

Gustav von Schmoller,

The Idea of Justice in Political Economy, 1881. 


\section{Introduction}

"I do not know", Alexis de Tocqueville says in Democracy in America, "if one can cite a single manufacturing and commercial nation - from the Tyrants to the Florentine and the English, - that has not also been free. Therefore a close tie and a necessary relation exists between those two things: freedom and industry." Tocqueville expresses what could be called a development truism of half a thousand years from late Renaissance citystates to Marshall Plan and Havana Charter. Indeed, during the Enlightenment, civilization and democracy were understood, through the analysis of people like Montesquieu and Voltaire among many others, as products of a specific type of economic structure. When German economist Johan Jacob Meyen stated in 1770 that "it is known that a primitive people does not improve their customs and institutions later to find useful industries, but the other way around", he expressed something which could be considered common sense at the time. We find the same idea - that civilization is created by industrialization or, to put it more specifically, by the presence of increasing returns activities - in the 19th century in thinkers across the whole political spectrum from Abraham Lincoln to Karl Marx. Industrialization "draws all, even the most barbarian, nations into civilization" as Marx puts it. What might be called the historical development consensus saw, in other words, the aim of development in the creation of middle-income economies - with all the accompanying values and culture that in turn were perceived as highly conducive to further sustained development. However, as Figures 1 and 2 show, the creation of middle-income economies has become a true rarity in the last three decades. 
Figure1. GDP per person employed, index (1980 = 100), 1980-2006.

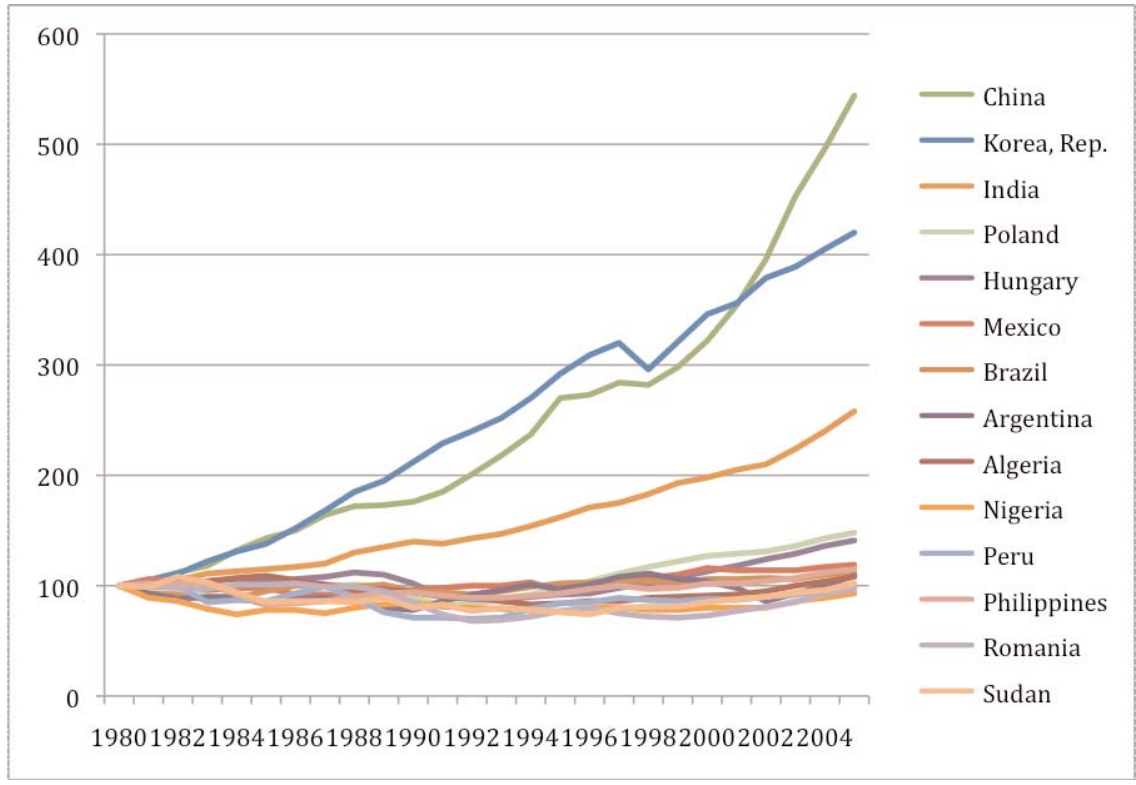

Source: World Bank WDI online database.

Apart from East Asia's much praised experience and the enormous catching-up taking place in China and, to a lesser degree, in India, the rest of the developing world from Eastern Europe to Latin America and Africa is experiencing strong cognitive dissonance.

Figure 2. GDP per capita in selected developing countries, 1950-2001 (in 1990 international Geary-Khamis dollars)

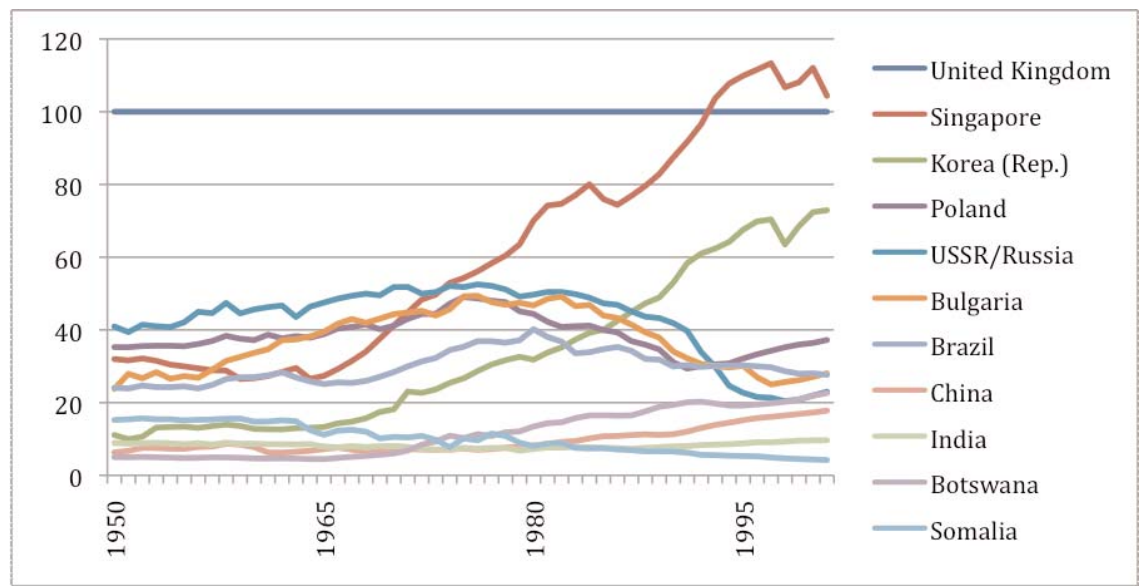

Source: Original data extracted from Maddisson $2003 .^{1}$

1 We would like to thank Yves Ekoué Amaïzo for his help with the data used in Figures 2 and 3. 
While many of these countries have seen significant growth in exports and in foreign capital inflows, their income levels have flatlined since 1980 and in most cases actually dropped in the 1990s. (Figure 1)

In fact, compared to highly developed countries, most developing countries were on a steady track towards catching up until the early 1980s; the subsequent decades show continuous and significant catching up - and actual surging ahead in the case of some countries such as Singapore - of East Asian economies. (Figure 2; see also Wade 2008) The trends follow rather precisely the changes in development thinking from classical development economics up to the late 1970 s to the Washington Consensus from the 1980s.

Figure 3. Growth rate of GDP per capita of selected world regions; regional average in selected periods between 1820 and 2001; annual average compound growth rate.

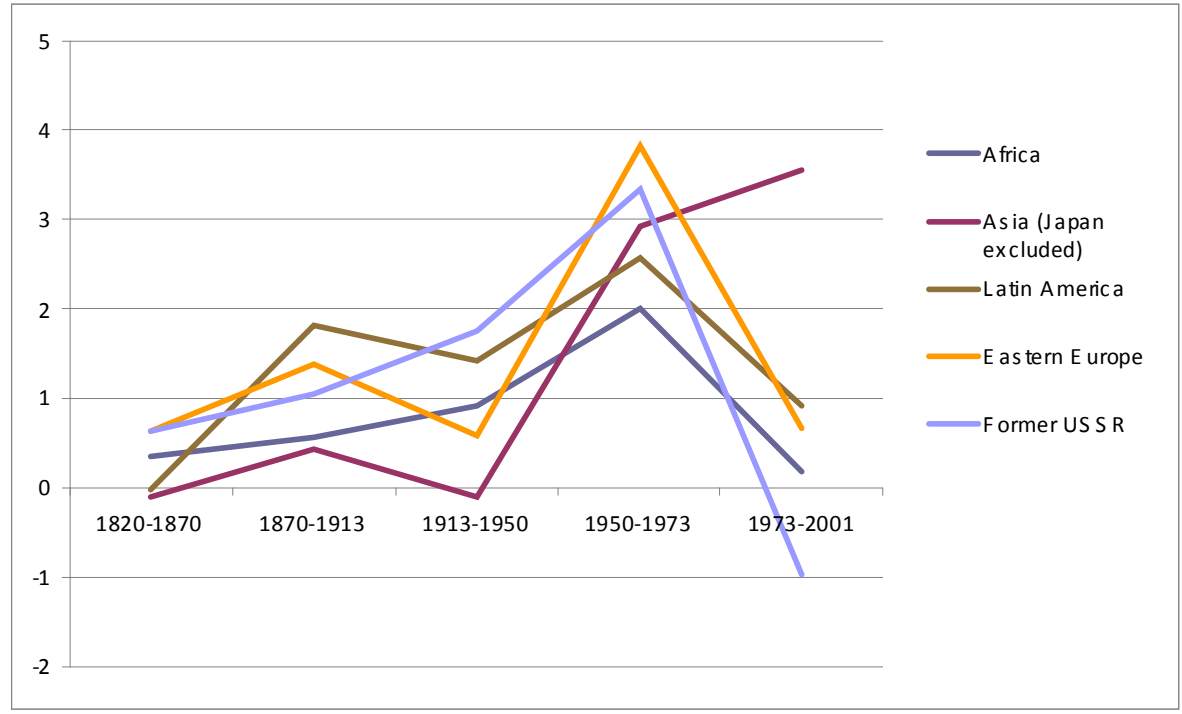

Source: Original data extracted from Maddisson 2003.

Moreover, as Figure 3 shows, in recent decades, most developing regions - again with the exception of East Asia - experienced growth rates that go clearly against the more or less positive trend of the last 200 years from a long-term historical perspective. In other words, the world after the industrial revolution has not seen such a dismal development performance. The Washington Consensus in development mainstream seems to be a failure on an unprecedented scale. 
Yet, surprisingly, the decades after 1980 have been called the best development decades in a generation (Rodrik 2007, 13-14; Skidelsky 2008). ${ }^{2}$ While Amsden argues, in contrast, that during these same decades, for most developing countries, "Heaven slowly gave way to Hell" (2007, 2), even the most ardent supporters of the Washington Consensus are forced to admit that there is something similar to the 'China price' in the development statistics of the poorer countries from 1980 onwards. If one deducts China's and India's growth from the developing countries' data, there is not much as far as growth and development in the rest of the developing world is concerned. And neither China nor India can be counted as showcases of the neo-liberal policies propagated by the Washington Consensus. We will return to this later.

As the World Bank itself admits, the rest of the developing countries, notably in Africa, Latin America and some of the former Soviet republics (in Central Asia, Moldova, Ukraine) suffer from heavy doses of a cognitive dissonance between promised growth and the reality of standing still, if they are lucky, or dropping backwards to income levels of earlier decades: "Whereas Latin America's income per head grew by 10 percent in the entire 25 years from 1980 to 2005, it grew by 82 percent in the 20 years from 1960 to 1980." (Amsden 2007, 6; also World Bank 2006; see also Chang 2007)

Latin America diligently followed policy reform suggestions yet failed to grow, as the World Bank also admits (World Bank 2006, 36-29); Eastern Europe and the former Soviet Union were equally willing to apply the policy reforms, and again, according to the World Bank's calculations, the recession these countries saw in the 1990s and many are still experiencing is worse than the Great Depression in the USA and World War II in Western Europe (in both cases, countries affected recovered considerably quicker). In fact, for example, "even if Ukraine managed to grow steadily at 5 percent a year, starting in 2002, it would take until 2017 to regain its previous peak - implying a transformational recession of more than a quarter of a century at best." (World Bank 2006, 33) Indeed, also for most Eastern European countries the recession was severe and lasted at least 10 years. (Reinert and Kattel 2007, Tiits et al 2008)

Coupled with the change of techno-economic paradigm that completely changed the nature of industrialization (outsourcing) and essentially stripped many maturing and increasingly footloose industrial activities of significant (dynamic) scale economies, Washington Consensus policies emphasising

\footnotetext{
2 To be precise, Rodrik and Skidelsky, similarly to many others, mean mostly poverty reduction in this context.
} 
FDI-led growth have created a truly toxic situation for many developing countries where initially the liability destruction was strong and quick but followed by slow asset creation. Thus, "the failure of the Consensus reform policies lies in the fact that they provided support for the 'destruction' of inefficient domestic industry, but failed to provide support for the 'creative' phase of 'creative destruction' of a real transformation of the productive structure through higher investment and technological innovation." (Kregel 2008) We will return to this topic as well. However, it seems rather obvious that the development community has unlearned how to create middleincome countries.

Yet, there is growing concern and evidence that the current form of globalization not only hurts developing countries that have followed the Washington Consensus policies, but is also harmful to the developed North. The flipside of the unlearning that has taken place in the development community seems to be that we are unlearning how to create middle-class jobs in the developed core countries. For all intents and purposes, non-existing growth in real wage in USA and Germany over the last decade has given ample reasons to start considering the impact of Washington Consensus trade policies on these countries, the most prominent examples being Samuelson's (2004) and Krugman's (2008) accounts. In 2004, Samuelson argued that continuing globalization and economic integration of world markets in its present form will do permanent harm to high-wage jobs in highly developed countries like the US. In early 2008, Krugman, another celebrity mainstream economist, argued that increased trade between US and developing countries is factually hurting US wages and middle-class jobs and thus increases income inequality. He goes on to prove this not only with US data but also with elaborate modeling.

What Krugman does not realize, or at any rate he does not say it explicitly, is that the problem lies not in the structure or policies of the US economy or even in the growing trade as such but in the nature of specialization of developing country exports. Specializing in lower-end production or services (also in sectors like ICT) virtually traps developing countries into lowwage jobs and, at the same time, lures the high-wage middle-class jobs away from the developed nations. Thus, while the global production grows, not all countries necessarily benefit from it. And, consequently, "firms maximize global output but do not necessarily maximize national income." (Palley 2006, 16)

In this introductory essay, we aim to show, first, how the classical development economics, that of Ragnar Nurkse's (1907-1957) generation, epitomized the best development practices of the past 500 years and crafted them into what Krugman rightly calls high development theory (1994). It is 
not a coincidence that the post-World-War-II era, when Nurkse and others ruled the development mainstream, is one of exceptionally good performance for many poor countries. Second, we argue that the alleged death of the classical development economics and subsequent rise of the Washington Consensus has to do not so much with increasing modeling in economics, a way of research purposely discarded by many classical development thinkers (as Krugman 1994 claims), but much more with misunderstanding the reasons for East Asia's success and Latin America's demise; we show that the root cause of this misunderstanding - that goes in fact back to 'misreading' key passages in Adam Smith - is the role of technology, or of increasing returns activities, and of finance, in development. Third, we aim to indicate key areas of further research that the current development mainstream should pursue in order to re-learn how to create middle-income economies and middle-class jobs.

\section{Classical Development Economics}

Pre-Smithian economics saw development as a goal created by increasing returns and innovations in manufacturing and not in agriculture, where stagnant productivity, diminishing returns and monoculture as well as the absence of synergies prevented growth. ${ }^{3}$ Furthermore, the targeting, support and protection of manufacturing - that is of increasing returns activities - were argued in terms of, first, its ability to create wealth; second, its ability to create employment; third, its ability to solve balance of payment problems; and fourth, its ability to increase the velocity of circulation of money. The connection between increasing activities and the creation of more or less stable and sustainable states with more or less liberal values can be seen as key throughout this entire tradition that reaches until the Marshall plan. Indeed, from as early as Giovanni Botero (1588) and the Staatsraison ("reason of state") tradition, there are clear links between economic structure and the viability of states. This tradition was continued by $18^{\text {th }}$-century social scientists and by Friedrich List, directly linking manufacturing and 'civilization'. In fact, already in early German social science, Veit Ludwig von Seckendorff (1626-1692) found that Germany did not have the economic basis to create a society like the one observed and so admired in the Dutch Republic. Seckendorff's approach to making the state function better was intimately tied to changing the economic basis of the state itself, its mix of professions and industries and their geographical relocation within the realm. In the tradition started by Seckendorff, the Fürsten (Princes) were turned into modernizers by arguing that their Recht (right) to govern

\footnotetext{
3 The following paragraphs draw on Reinert 2007.
} 
was accompanied by a Pflicht (duty) to modernize and, in effect, in the long term create the conditions where the Fürsten in the end would be obsolete and the conditions needed for a functioning democracy would have been created. A successful Principality carried with it the seeds of its own destruction and the birth of democracy.

The first wealthy states with some kind of republican rule were often islands like Venice and the Dutch Republic. The absence of arable land both led to an absence of a feudal structure and contributed to the creation of a diversified economic structure including activities subject to increasing returns. This makes Florence, with power also by landowners, so interesting. There the corporazioni (guilds) and the burgers fought for power among themselves, but very early $\left(12^{\text {th }}-13^{\text {th }}\right.$ century) they had banned the families that owned the land around from participating in politics (these continued to trouble Florence for centuries through alliances with other cities).

There is, then, a long history of trying to move the vested interests of the ruling class from land to manufacturing. The rulers who had a manufacturing strategy also tended to have a policy against the land-owning nobility, starting with Henry VII in England in 1485.

In sum, there are a number of basic principles of development that can be observed in action from $15^{\text {th }}$-century Tudor England to the Marshall Plan. Despite all the theoretical and historical diversity that makes up this tradition of more than 500 years, one very simple formula sums it up rather effectively: a nation is better off with an inefficient industrial (increasing returns) sector than with none at all. Yet, part of this consensus is also the understanding that possessing an industrial sector, however inefficient, should be followed by increased trade in order to create competitive pressure for the industrial sector.

Classical development economics, while in itself a highly diverse group of economists and economic as well as policy ideas, is till today perhaps the best-articulated and theoretically grounded expression of the abovedescribed development consensus. And, as Krugman argues, the "irony is that we can now see that high development theory made perfectly good sense after all." (1994)

The group of economists commonly referred to as classical development economics or pioneers of development, or high development theory, is typically seen to consists of 4-6 key thinkers: Paul Rosenstein-Rodan, Hans Singer, Arthur Lewis, Albert Hirschman, Gunnar Myrdal and Ragnar 
Nurkse. ${ }^{4}$ While of this group, Nurkse's contribution is the strongest in terms of economic theory, Hirschman's accomplishments are perhaps the farthest-reaching in terms of influencing social science and development mainstream the most. Up to this day, it is relatively typical to find accounts that juxtapose precisely these two thinkers as representing almost exactly opposing ideas about development, namely balanced vs. unbalanced growth. However, as Hirschman later acknowledges, the differences between him and Nurkse were minor at the end of the day, and in large parts, they shared a very similar outlook. (Hirschman 1984; see also Nurkse 1961, 241ff)

In what follows, we base our brief account mostly on Nurkse's ideas accompanying them with bits and pieces from the other pioneers, mostly from Rosenstein-Rodan and Hirschman. ${ }^{5}$

\section{The high development theory developed by Nurkse and others rests on two key ideas:}

First, financing for development has to come to a large extent from the developing country itself ("Capital is made at home"; Nurkse 1961, 141), and

Second, the key areas to be financed need to exhibit increasing returns in order to trigger dynamics of development or, as Myrdal argued, virtuous circles of growth. ${ }^{7}$

What makes Nurkse's contribution so important is the fact that he is the only thinker from this group to, first, incorporate both key ideas into a coherent theory of development and, second, to draw clear relationships between these notions. ${ }^{8}$ Indeed, this is precisely the reason Nurkse favored the balanced growth approach over the unbalanced one (the difference,

\footnotetext{
4 There are a number of other thinkers that played key roles in early development theory who could be mentioned here as well, for instance Raul Prebish, W.W. Rostow and others. A good collection of recollections by the key figures in this tradition is gathered in Meier and Seers 1984 (although this does not include Nurkse as he had passed away by the time of this publication).

5 We are necessarily generalizing, for more detailed accounts we refer the reader to subsequent contributions in this volume.

6 While Nurkse 1961 is a collection of his various works, we refer to this publication as a whole.

7 For Nurkse, key passages are Nurkse 1953, 19-25.

8 Krugman 1994, for instances, discusses only the aspect of increasing returns and fails to note how this is related to financial issues.
} 
simply put, being between whether one industrializes in numerous or just few key areas): the former was deemed by Nurkse to be financially more stable than the latter. $(1961,241 \mathrm{ff})$

According to Nurkse, the financing for development has to come mainly from within the country set on development because financing of growth through either foreign investments or increased trade was largely a historically unique phenomenon confined to the $19^{\text {th }}$ century and more specifically to American experience. (See, e.g., Nurkse 1961, 134-136; 282-286) The 'new countries' within and without the British Empire were "high income countries from the start: effective markets as well as efficient producers." $(1961,243)$ Nurkse thought that it would be nearly impossible for any developing country to repeat such a successful trade- and foreignfinancing based growth strategy because America was highly rich in resources but at the same time populated by workforce essentially on the same skill level as Britain. $(1961,143)$ This unique combination made the American experience non-replicable because in any other circumstance, trade and foreign investment would engender a number of obstacles to development. Namely, first, large parts of such financing would seek to utilize poor countries resources and eventually lock these countries into undiversified economies with a skewed social structure; (Nurkse 1961, 100, $137,144,248$ ) and second, there is clear danger that significant amounts of foreign financing would end up funding private consumption patterns emulating Western living standards and thus creating balance of payments problems (Nurkse 1953, 66-70).

To sum it up, a growth strategy simply based on trade and foreign financing would leave the poor countries with negative financial flows and undiversified production structure - just like the Washington Consensus, as we will show below -, and this amounts to financial fragility or to a Ponzi financing position. The problem with such a strategy is that it relies on foreign financing to balance the current account, and this can take place only under very specific conditions: "it is only possible to maintain a development strategy based on net imports financed by foreign capital inflows if the interest rates on the foreign borrowing are equal to the rate of increase of foreign borrowing. If interest rates are higher than the rate of increase of inflows ... the policy will eventually and automatically become self-reversing as the current account becomes dominated by interest and profit remittances that exceed capital inflows." (Kregel 2004, 11) This, arguably, is what has made various growth efforts in developing countries so difficult to sustain in the last few development decades: many growth strategies are simply based on self-reversing logic, and this is indeed what Nurkse clearly foresaw. 
Thus, according to Nurkse, any economic strategy that wants to be sustainable in the long term has to come up with another way of financing the development. What this, however, means is that such a development strategy has to work in a relatively confined environment in terms of capital and skills. Taking into account the financial constraints described above, it is in this context that Nurkse interprets Adam Smith's famous theorem about the size of the market being limited by the division of labor. For Nurkse, following Allyn Young's 1928 essay, this theorem indicates that the size of the market is limited by real wages that are, in turn, limited by productivity growth. (1953, 21-25) For Nurkse, and very clearly for Hirschman and Rosenstein-Rodan, productivity growth is determined by the presence of increasing returns in an economy. (Nurkse 1953, 8, 14; also Nurkse 1961, 5-9, 27-29, 32; Rosenstein-Rodan 1984) Thus, a viable development strategy should aim at establishing a number of increasing returns activities that would become each other's customers and generate the first virtuous circle of growth. The size of the market is limited by the number of increasing returns activities present at the particular market. This dynamics is the essence of Nurkse's balanced growth, but also of Rosenstein-Rodan's big push and, in the end, also of Hirschman's unbalanced growth, expressed in very similar wording.

The expansion of the market can be realized only through a process of balanced growth, where people in different industries, working with more and better tools, become each other's customers. (Nurkse archives, Box 8; see also Nurkse 1961, 252);

... new producers will be each other's customers, and the complementarity of demand will reduce the risk of not finding a market. Risk reduction is in this sense a special case of external economies. $(1984,213)$

Hirschman argues that such an interrelatedness - which he called backward and forward linkages - does not happen simultaneously but rather in a sequential process of learning and development and that in this process, the role of public policy or development strategy in setting goals and advancing specific sectors is key. ${ }^{9}$ Nurkse's most serious argument against this is that such unbalanced growth will very probably need to rely on foreign financing at some point, as also Hirschman admits (1984, 103). As we have argued above, due to the specific nature of such foreign financing (extractive in its nature and easily engendering lock-in effects, plus financing the consumption of imported goods), Nurkse was wary that such a strategy would lead to financial fragility. (1961, 247-253) As we have argued above, this proved to be a highly far-sighted concern.

9 Hirschman discusses his relationship to Nurkse and Rosenstein-Rodan most explicitly in Hirschman 1984, see especially 96-97. 
It is important to note that most subsequent accounts of big push and balanced growth theories only emphasize the idea of consorted investments, mostly missing the point that, first, these policy efforts should target increasing returns activities and that, second, the reasoning behind this has to do with financial stability (see, e.g., Easterly 2008).

In order to create increasing returns activities, infant industry protection may be necessary according to Nurkse and others, but it is also more important here to realize that the argument is less about protection but about what is specifically targeted with the protective policies and how: infant creation is more important than infant protection. (Nurkse 1961, 247, 257; 1953, 104$105,109)$ Indeed, perhaps the key idea behind targeting increasing returns activities is that the resulting virtuous circles of growth (productivity and wage growth) act as barriers of entry for competitors both in terms of private companies but also in terms of regions and countries. (See also Reinert 1980, Gomory and Baumol 2004) The reason is evident in the very logic of balance growth: virtuous circles of growth relay and create their own demand and financing. (Nurkse 1961, 296) Thus, the driving idea behind Nurkse's balanced growth is not simply a set of reasons and/or policies for the creation of diversity in increasing returns activities, but moreover to show that both as a theoretical foundation and as a policy strategy, balanced growth is coherent and sustainable as it shows how long-term growth with financial stability can be achieved and maintained. In sum, Nurkse's balanced growth shows how middle-income nations can be created.

The quest to create middle-income economies as the main goal of development can also be stated differently: how to upgrade developing countries' economic structures with raising wages and without beggar-thy-neighbor type of policies for instance in foreign exchange rates, labor markets, tax rates, and so forth. (See also Summers 2008) This, however, is largely the way competitiveness has come to be defined by international organizations like OECD and the European Union. Interestingly, however, this definition of competitiveness comes from a 1985 Reagan administration report Global Competition: The New Reality by the President's Commission on Industrial Competitiveness (see Scott and Lodge 1985 as background). Historically, however, this goes back further to the Bretton Woods agreements, in particular the one that established the IMF, where under article I.2, it states the aim of the IMF as follows: "To facilitate the expansion and balanced growth of international trade, and to contribute thereby to the promotion and maintenance of high levels of employment and real income and to the development of the productive resources of all members as primary objectives of economic policy." The key background publication for these ideas was the League of Nations publication from 1944 titled International Currency Experience: Lessons of the Inter-war Period and mainly written by 
Nurkse. (See further Urban in this volume) This does not only show the breadth of Nurkse's influence, but also shows why his and his generation's development ideas are so relevant today: the strategy proposed by classical development economists is, first, based on a historically proven recipe of targeting increasing returns activities and, second, doing so under more or less financially stable conditions. It also shows, however, that following the path of balanced growth makes it clear that there is a need for global balancing rules as well. While the post-WWII era showed that this can indeed be done, the year 2008 has taught that such global financial rules are direly needed again.

Krugman (1994) argues that the decline of high development theory has methodological reasons: "so why didn't high development theory get expressed in formal models? Almost certainly for one basic reason: high development theory rested critically on the assumption of economies of scale, but nobody knew how to put these scale economies into formal models." Krugman admits that in particular Hirschman and Myrdal were consciously against increasing modeling in economics. His own argument that modeling is inevitable in economics is based on two simplifying assumptions: first, science is based on models and second, models need to be mathematical. While both assumptions are, to say the least, debatable (see in particular Drechsler 2004 for an excellent discussion), putting the blame on the doorstep of high development theory, Krugman along with much of the economics profession completely misses the other side of the story: how model-based economics interpreted post-World-War-Il development stories. As we will argue below, because the model-based economics assumed away increasing returns and technology from development, it was left with tools Nurkse and others deemed counter-productive when used without targeting precisely the increasing returns activities: trade openness and foreign financing as the main engines of growth. As the saying goes, if all you have is a hammer, pretty soon all problems look like nails. This is precisely what happened. While high development theory argued for a context-specific approach and tailor-made policies - because economic activities, technology, knowledge and economies of scale change enormously in time and space - the new development consensus on the rise in the 1980s and in full sway to this day argues the opposite: all developed problems are fundamentally alike, and thus, solving them should go by more or less the same policy prescriptions. The success of such an approach lies in the very nature of development: as Hirschman argues, all development presupposes some form of priority setting through policy making. (Hirschman 1958) The Washington Consensus did away exactly with this assumption: since all development problems are assumed to be of the same nature, the solutions are bound to be the same as well, and this takes the burden of proof, so to say, away from domestic policy-making. 


\section{Washington Follies}

It has been more or less thirty years since the alleged death of classical development economics. The 'demise' was precipitated by the onslaught of "The Age of Milton Friedman" ${ }^{10}$ and by what about fifteen years ago became more widely known as the Washington Consensus. ${ }^{11}$ It can be argued that it was truly an intellectual "counter-revolution", a term used both by the supporters and the critics (see Johnson 1971 and Klein 2007 respectively). The counter-revolution, whatever its ideological core or its public enemies may have originally been (be it development economics proper, Keynesianism or Bastard Keynesianism) ${ }^{12}$ was in its core aimed at juxtaposing two seemingly different development traditions: East Asia's rise and Latin America's doom in the 1970s and 1980s. However, this was only possible by showing, first, that East Asia's rise was based on using policies based on classical Ricardian comparative advantage thinking and using exports as an 'engine of growth' (see from Balassa 1971 to Rodrik 2006 and World Bank 2008a), and second, that Latin America's problems had its roots in failed or at least mismanaged import substitution industrialization, closely related with the classical development economics (see from Bhagwati 1984 to Rodrik 2007).

In both cases, the counter-revolutionaries or their descendants got it wrong: exports were only a part of the success story in East Asia's rapid rise, and import substitution played only a relatively insignificant part in Latin America's fall.

East Asia's story was told in a way as if feedback linkages and positive externalities emerging in these economies through state-led industrialization played only an exogenous role in development. ${ }^{13}$ That is, technology and innovation were simply left out of the story, and a rather simplistic conclusion was drawn: export-led growth is what works in development countries. Latin America's problems, in turn, were seen through a double prism of inflation and rent-seeking, without, however, realizing that increasing foreign private lending in the 1970s also spurred the consumption engine into higher gear, which was bound to lead to the current account problems (through import consumption) and eventually towards long-lasting financial fragility that undermined industrialization efforts, and not the other way around. (Kregel 2008) That is, the role of the post-Bretton Woods interna-

\footnotetext{
10 Schleifer 2008; see Galbraith 2008 from the opposite perspective.

11 Classic reference is Williamson 2002 summarizing "what Washington means by policy reform", originally published in 1990; see also Williamson 2008.

12 For accounts from rather different perspectives, see Toye 1987 and Klein 2007.

13 Wade 2004 is an excellent overview.
} 
tional financial architecture was ignored and, in fact, together with the newly learned 'lessons' from East Asia about export-led growth, it was precisely the accelerating financial liberalization that was seen as the main source of the much-needed capital for the export-led growth model. ${ }^{14}$ Two plus two equals five: development needs foreign investments and exports, and both could be provided by a stable macro-economic environment and liberalized markets. In sum, two misinterpretations ended up providing a new model for development that evolved into the Washington Consensus as a full-fledged ideology and set of policies.

Significantly, both misinterpretations marked a break with a long-standing development tradition reaching back to the Renaissance (see Reinert 2007 in detail) -that was, however, also supported by many if not most neo-classical economists at the time (excellent summary is Evans and Alizadeh 1984) - namely, that infant industry protection is a necessary if not sufficient condition for industrialization and diversification. Also Williamson's original list of Washington Consensus policies included infant industry protection, and "a moderate general tariff (in the range of 10 percent to 20 percent, with little dispersion) might be accepted as a mechanism to provide a bias toward diversifying the industrial base without threatening serious costs". (2002) Neither made it into the Washington Consensus practices in the 1990s or into its augmented version of the 2000 s. $^{15}$

With these misinterpretations, however, not only were real developments misunderstood, equally important is to note that comparing East Asian and Latin American development experiences yields key lessons about the success and failure of development strategies. More precisely, perhaps the key lesson is that protectionism does not equal protectionism. If development history teaches us that infant industry protection is a conditio sine qua non, then it is exactly the comparison of two very recent instances of this strategy that can teach us the reasons for success and failure. Indeed, based on these two historical experiences, we can create two 'ideal types' of protectionism. In Table 1, we try to distill from vast and diverse historical data and different contexts two such 'ideal types'.

\footnotetext{
14 Blecker 2000 provides an overview of export-led growth strategies.

15 A useful discussion of international agreements and industrial policy space is Rodrik 2007, 129-148. For Augmented Washington Consensus, see Rodrik 2006.
} 
Table 1: Ideal types of protectionism compared.

East Asian

Latin American

\begin{tabular}{|c|c|}
\hline $\begin{array}{l}\text { Temporary protection of new industries/products for the world } \\
\text { market }\end{array}$ & $\begin{array}{l}\text { Permanent protection of mature industries/products for the home } \\
\text { market (often very small) }\end{array}$ \\
\hline Very steep learning curves compared to the rest of the world & Learning that lags behind the rest of the world \\
\hline $\begin{array}{l}\text { Based' on a dynamic Schumpeterian view of the world - market- } \\
\text { driven 'creative destruction' }\end{array}$ & Based on a more static view of the world - planned economy \\
\hline Domestic competition maintained & Little domestic competition \\
\hline Core technology locally controlled & $\begin{array}{l}\text { Core technology generally imported from abroad/assembly of } \\
\text { imported parts/'superficial' industrialization }\end{array}$ \\
\hline $\begin{array}{l}\text { Massive investment in education/industrial policy created a huge } \\
\text { demand for education. Supply of educated people matched } \\
\text { demand from industry. }\end{array}$ & $\begin{array}{l}\text { Less emphasis on education/type of industries created did not } \\
\text { lead to huge (East Asian) demand for education. Investment in } \\
\text { education therefore tends to feed emigration }\end{array}$ \\
\hline $\begin{array}{l}\text { Meritocracy - capital, jobs and privileges distributed according to } \\
\text { qualifications }\end{array}$ & Nepotism in the distribution of capital, jobs and privileges \\
\hline Equality of land distribution (Korea) & Mixed record on land distribution \\
\hline $\begin{array}{l}\text { Even income distribution increased home market for advanced } \\
\text { industrial goods }\end{array}$ & $\begin{array}{l}\text { Uneven income distribution restricted scale of home market and } \\
\text { decreased competitiveness of local industry }\end{array}$ \\
\hline Profits created through dynamic 'Schumpeterian' rent-seeking & Profits created through static rent-seeking \\
\hline intense cooperation between producers and local suppliers & Confrontation between producers and local suppliers \\
\hline $\begin{array}{l}\text { Regulation of technology transfer oriented toward's maximizing } \\
\text { knowledge transferred }\end{array}$ & $\begin{array}{l}\text { Regulation of technology transfer oriented towards avoiding } \\
\text { 'traps' }\end{array}$ \\
\hline
\end{tabular}

Comparing the two, it is clear that key differences between these 'ideal types' rest precisely in the issues that especially Nurkse, but also other early development economists, thought fundamental to development. First, the idea that development needs specific economic activities that exhibit longterm potential in terms of learning curves, home-market expansion and exports. Such activities provide dynamic increasing returns that in turn create possibilities for continuous upgrading through educational, labor-market and other policies. This is what East Asian countries did; Latin American countries failed to target windows of opportunities in different activities and a need for competitive pressure was underestimated. Second, the failure to create dynamic economies of scale led to financial fragility relatively easily, in particular when foreign capital inflows and lending became prevalent elements in the development strategy, as happened in Latin America in 1980s.

These lessons, however, were almost completely missed by the Washington Consensus. ${ }^{16}$ Moreover, what is historically significant is the

\footnotetext{
16 It is interesting that China's development strategies over the last few decades exhibit the results of this skewed learning process in international development mainstream: while in the 1980s, China seemed to be on the path towards the East Asian type of capitalism where a mix of competitive markets and technology targeting is a key element, then, reflecting the rise of the Washington Consensus in the 1990s, China switched to an export-led growth strategy that, however, also exhibits certain elements from the Latin American type of development: nepotism and static rent-seeking in the policy environment and uneven income distribution. For an intriguing study of Chinese capitalism, see Huang 2008.
} 
fact that the classical development economists were largely made the culprits of Latin America's problems. It is all the more puzzling when one reads the original works of these authors and looks at the subsequent history; it becomes clear, as we have shown above, that it is their theories that predicted both East Asia's rise (understanding the key role of technology and diversity) and Latin America's doom (understanding financial fragility built into foreign-financing-led growth strategies). Interestingly, Williamson's article on the Washington Consensus ends with doubt and a premonition along similar lines of thought:

A striking fact about the list of policies on which Washington does have a collective view is that they all stem from classical mainstream economic theory, at least if one is allowed to count Keynes as a classic by now. None of the ideas spawned by the development literature-such as the big push, balanced or unbalanced growth, surplus labor, or even the two-gap model-plays any essential role in motivating the Washington consensus ... This raises the question as to whether Washington is correct in its implicit dismissal of the develop ment literature as a diversion from the harsh realities of the dismal science. Or is the Washington consensus, or my interpretation of it, missing something?

As we have seen above in Figures 1-3, Washington Consensus policies not only failed to deliver growth and development to most developing countries, following such policies seems to have been almost a blueprint for falling back rather than catching up. Such an enormous, and as we have shown above, historically unprecedented negative impact goes back to two key misunderstandings: first, the role of technology and increasing returns, and second, the role of institutions. However, before we discuss these, it is pivotal to understand that what made the 1990s particularly 'crazy' in terms of development was the coincidence of implementing Washington Consensus policies and the change in techno-economic paradigm. We argue below that this made export-led growth underlying Washington Consensus policies a race to the bottom or beggar-thy-neighbor environment because trade and technology were essentially decoupled both in theory and in policies.

Carlota Perez, the inventor of the concept of techno-economic paradigms, has briefly summarized the idea of techno-economic paradigms as follows:

There has been a technological revolution every 40 to 60 years, beginning with the Industrial Revolution in England at the end of the 18th Century; each has generated a great surge of development, diffusing unevenly across the world from an initial core country. ... The great wealth creating potential provided by each of them stems from the combination of the new technologies, industries and infrastructures with a set of generic technologies and organisational principles capable of modernising the rest of the economy. The resulting best practice frontier is superior to the previous one and becomes the new common sense for efficiency - a new techno-economic paradigm - that defines the 
guidelines for innovation and competitiveness. ... The propagation is highly uneven in coverage and timing, by sectors and by regions, in each country and across the world. (Perez 2006; see also Perez 2002)

The paradigms describe how the technological change and innovation of a given period are most likely to take place: organizational forms and finance that are conducive to innovations, what technological capabilities and skills are needed, and so forth. Accordingly, the new ICT-based techno-economic paradigm, coming to full force in 1990s, has engendered key changes in production processes in almost all industries (including many services and agriculture): outsourcing and the resulting geographical dispersion of production functions. These changes have enabled very fast growth in foreign capital inflows into developing countries as well as industrialization (e.g., in terms of growth rates of manufactured and high-tech exports). However, in many cases the outsourcing activities do not exhibit the same dynamics that used to be associated with them in the originating countries - fast and sustained productivity growth, raising real wages, forward and backward linkages - but rather the opposite. (See for detailed discussion and data, e.g., Palma 2005; Cimoli, Ferraz and Primi 2005; Tiits et al 2008) Thus, the key assumption of comparative advantage trade models and theories fell away: even if high technology exports have been growing in developing countries, this does not mean that we deal with similarly dynamic sectors with significant increasing returns. (See also Krugman 2008) In result, increasing global trade easily increases production and investment but not necessarily global wealth, and, consequently, the allocation of production across the countries may well be globally inefficient. (Palley 2006, 10) Due to the changing techno-economic paradigm, integrating developing countries into the world economy has become an increasingly asymmetrical affair in many ways.

Coupled with the change of techno-economic paradigm, Washington Consensus policies emphasising FDI- and export-led growth have created a truly toxic situation for many developing countries, especially in Latin America and Eastern Europe, where liability destruction was strong and quick initially but was then followed by slow asset creation.

In sum, the Washington Consensus has left many developing countries with an almost completely changed economic and industrial structure that is deeply different from and much less skill- and technology-intensive than the previous structure. This explains the fast growth but also why they do not catch up with the Asian economies in terms of productivity and income growth witnessed in Figures 1 and 2 above. 
As we have mentioned above, there are two reasons why the Washington Consensus and its descendants run into problems on the level of theory and in particular on the level of practical advice, and are constantly criticized by Schumpeterian/evolutionary/institutional economists: ${ }^{17}$ the specific, narrow and eventually misleading understanding of technology and institutions. It is difficult to argue that neither is significant for growth and development, and thus, hardly any economist these days argues against the importance of technology or institutions. Indeed, there is a growing trend to pay rather extensive lip service to both. The latest fashion in development seems to be precisely the mix of 'getting the institutions right' and 'getting the technology right'. Jeffrey Sachs and the World Bank (as proxies for the reigning consensus) advocate that, first, institutional and not simply policy reforms are key to long-term growth, and second, development strategies should be based on technology as one of the key drivers of long-term growth. While both ideas seem very close to what long-term Schumpeterian critics of the Washington Consensus have advocated, in reality there is hardly any change in development advice, and the inclusion of both technology and institutions follows a deeply faulty logic.

While Sachs argues that "the very science and technology that underpin prosperity in the rich world are potentially available to the rest of world as well" (2008, 205), the World Bank wonders "[w]hy is it that existing proven technologies are frequently not adopted by people who presumably would benefit most from these technologies" (2008b, 3; see also World Bank 2008a, 18) This is not far from the neo-classical assumption that technology is exogenous to growth since technological development is seen here largely as a linear step-by-step development towards complexity and as essentially open for various competitors to step up and join the ride. This is simply not true. In business terms, this equals arguing that since there is a huge market for computer operating systems, one of the best businesses in town should compete with Microsoft's Windows. That this strategy can be, if at all, taken up perhaps only by Google shows how ridiculous the assumption is that technology is freely available to all.

Seeing technology as yet another neutral ingredient that can be added at will into the development blender gravely misunderstands the process of creative destruction that characterizes capitalist growth. And while the recent publications by the World Bank do actually refer to creative destruction (see, e.g., World Bank 2008a, 26, 44-45), it is usually done in an extremely narrow sense to mean entry of new firms and dissolution of old ones. Technological development is anything but linear and technology is

17 Excellent and authoritative summary is Cimoli et al 2006. 
anything but freely available. Path dependencies, linkages, spill-overs, externalities, winner-takes-all markets and highly imperfect and dynamic competition make technology an unpredictable, high-risk and possibly high-return endeavor that drives on a tautological logic: technological development feeds on technological development. (See, e.g., Arthur 1994, Perez 2002) Even more importantly, technology is a man-made comparative advantage that creates havoc in the Ricardian comparative advantage model. What technological development shows is that that the key is not trade as such but what kind of trade and with whom. (See Gomory and Baumol 2004, and Palley 2006 for a brilliant discussion) Indeed, trade models without technology and increasing returns advocate a policy environment that is bound to lead to beggar-thy-neighbor policies either through exchange rate depreciations, technological know-how restrictions or the Latin American type of protectionism described above. Palley describes this logic in the following terms:

First, countries do not benefit from autarky (self-sufficiency) because they lose the benefit of economies of scale. Second, countries still want to retain a more than proportionate share of industry, as this objective restricts global output and drives up prices of goods. Since the countries also export these goods, this objective confers a terms-of-trade benefit that increases income. (Palley 2006, 13)

Models and policies that do not assume increasing returns essentially decouple trade and technology. As we have shown above, successful development from the last 500 years teaches us exactly the opposite: successful trade policy is largely a technology policy.

As far as institutional change is concerned, it has been argued that most developing countries did not reform enough or failed to implement properly Washington ideas: "meant well, tried little, failed much" (Krueger 2004). The consensus ideas about institutional reform are based on one simple assumption: institutions are "the rules and norms constraining human behavior" (World Bank 2006, 5). The author most often associated with this line of argument is Douglass North and yet somewhat surprisingly one of the harshest criticisms of the World Bank blend of institutionalism and policy reform comes precisely from him (just substitute, for simplicity's sake, open access societies with developed countries and natural states with poor societies):

The economists' natural prescription is to suggest that a country 'reform'; that they systematically adopt policies that mimic those in open access order: less regulatory control, absence of monopolies, more secure property rights, improved public goods provision such as education and more markets. Such an approach ignores the fact that natural states adopt limited access policies not just to maximize the incomes of the ruling elite, but because limited access poli- 
cies address the problem of violence by giving individuals and groups with access to violence an incentive to cooperate. Policies from open access orders - universal, impersonal rights and rule of law - reduce the natural state's ability to control violence. These changes threaten to make people worse off, not better off. ... The transfer of institutions from open access orders to natural states cannot, in and of itself, produce political and economic development. (North, Wallis and Weingast 2008, 15)

North et al. indeed point to a key problem inherent in many of the Washington Consensus ideas about institutions, namely that an institutional setting can be transformed from one society to the next. Such a universal claim makes it possible to reverse the development logic: in any given country, one does not start with problems but rather with solutions. Perhaps the best example is the recent work by the World Bank that advocates openness and context-specific solutions to development problems but only as long as the diagnosis and solutions are based on the market failure approach. (World Bank 2006; World Bank 2008a) This is of course a mirror image of the Washington Consensus approach: the latter operates with predefined solutions, the 'new' approach with predefined problems. The Washington Consensus is far from over, it just comes in many new disguises.

Even if it is possible to argue that by now the Washington Consensus has turned into Washington Confusion (Rodrik 2006), there is scant if any evidence that policy advice given to developing countries or analytical work done by the Washington institutions has in substance changed at all (Rodrik also admits this). What is more, there is a growing tendency to deal with symptoms such as mosquito nets, debt relief and the like. It is obviously nonsensical to argue that such activities should not be undertaken. It is however equally clear that such palliative pop star economics, chiefly advocated by Jeffrey Sachs (2005 and 2008) and embodied in UN's Millennium Development Goals, will do almost nothing to put poor countries on a sustainable development track. Quite the opposite, it can also be argued that such treatment of symptoms entraps poor countries into Malthusian boombust cycles of population growth and hunger. As Clark argues, "the subsistence wage, at which population growth would cease, is many times lower in the modern world than in the preindustrial period. ... Given the continued heavy dependence of many sub-Saharan African countries on farming, and a fixed supply of agricultural land, health care improvements are not an unmitigated blessing, but exact a cost in terms of lower material incomes." $(2007,45)$

Thus, while the former Washington Consensus writers readily admit for a greater role of technology and institutions in development, their assumptions and conclusions seem to lead right back to the Washington Consensus 
mode of understanding the development issues. An interesting example is Rodrik's work and, by default it seems, also most recent thinking in the World Bank. Rodrik's suggestions for industrial policies in the $21^{\text {st }}$ century are hardly if at all compatible with his self-proclaimed neo-classical approach and with his "growth diagnostics". While the latter two are obviously based on the concept of market failure (or government failure that causes market failure, the result is the same, namely market failure), most of his policy principles and incentives could have been written by an Schumpeterian economist. Rodrik's policy advice ranges from "incentives to 'new' activities", through a "built-in sunset clause" to demanding that "activities that are subsidized must have the clear potential of providing spillovers and demonstration effects" and to subsidizing R\&D and "general technical training" (2007, 114-119). Such policies do not necessitate market failure as a concept to understand the need for them; market failure and the neo-classical approach, however, makes the application of these ideas context-blind. Clearly, if one assumes a key role for technology in economic growth, one has to give up market failure as a concept as technologically driven growth is by definition imperfect. Entrepreneurs seek technological innovation in order to create market failures. As most economists, Rodrik, too, thinks that the answer lies in better governance to avoid such pitfalls. And, as many before, Rodrik is fundamentally governance-blind and does not realize that the same Washington whirlwind of change has swept through policy advice on governance as well (on Rodrik's ideas on governance, see Rodrik 2008).

Indeed, what looked like a set of hardcore economic policies - neutral to politics or morals for that better, and thus free of rent-seeking, a proper there-is-no-alternative or TINA (see already Hirschman 1984) - was in fact accompanied by a similar sea change in policy making. Rolling the state back was accompanied by hollowing the state out. This meant that not only did the policy space became strictly defined, also the way policies were implemented was radically redefined. New public management or NPM was as fast and furious in its onslaught as the Washington Consensus.

While there is a relatively long tradition of making a caricature out of Weberian or classical bureaucracy that emphasises rule of law, clear hierarchies, merits and competence (Lynn 2001 for a good overview), what came to be the meeting point for economic policy and governance reforms is the loss of increasing returns or technology from their framework of thinking. While Krugman (1994) and others have documented how mainstream economics lost scale economies due to increasing modeling in the aftermath of the WWII, it is interesting that one branch of economics that seemingly retained scale economies, interpreted them in an highly specific way. 
From the beginning of their theoretical endeavors, public choice theorists have concentrated upon a specific kind of scale economies, namely those limited by regulation and/or monopolistic markets. Indeed, one can follow this specific way of understanding increasing returns from Stigler 1951 to Buchanan and Yoon 2008. Public choice theorists go explicitly back to Smith's theorem about the division of labor being limited by the extent of the market and argue that Smith's accomplishment is in the "replacement of the mercantilist world of monopolies and cartels by competitive markets". (Buchanan and Yoon 2008, 187) It is quite clear that public choice theorists look almost solely at what can be called internal scale economies. In fact, this line of argument (looking only at internal scale economies) can be traced back to Viner's discussion of trade theory in the 1930s (Viner 1937), who is similarly worried about the potentially monopolistic impact of internal increasing returns. ${ }^{18}$ (See also Reinert 1980, 117-121) In this line of argument the increasing returns might engender monopoly rents and stifle competition, consequently policy focus should not be on creating activities with such returns, or not foremost, but on alleviating the market-limiting impact of such monopoly rents. This, in essence, forms the foundation for the market failure approach discussed above. The entire enormous impact of external and historical increasing returns is left out of the argument, and this has had grave consequences for the way public choice and mainstream economists in general understand the role of the state in economic growth. Since competitive environment is seen as the guarantee for extending market size (and, along the way, lowering prices for consumers) and increasing division of labor, the government's main task is to ensure and maintain such an environment. However, in particular public choice theory takes it much further than that. Namely, according to this theory, the best way to ensure that government actually looks after the competitive environment is to inject market discipline also into government activities. Thus, the government should outsource and privatize as many activities as possible, there should be markets for public services wherever possible, there should be internal markets within government, public servants should be paid according to their performance and so forth.

What came to be known in the 1990 s as new public management ${ }^{19}$ thus has its origins in interpreting increasing returns in a very specific way. The results, however, have been as disastrous for developing as for developed countries. As one commentator puts it, "as more and more state functions

\footnotetext{
18 Somewhat ironically, it was Viner who called Nurkse to Princeton faculty just before the latter's death (Nurkse accepted the call, but never started to work in Princeton, however this is the reason his archive is in Princeton). See Viner's letter to Nurkse from December 22, 1958, in Viner's archive in Princeton, II Correspondence, 1. General correspondence, NI-NY.

19 An excellent summary on the rise and fall of New Public Management is Drechsler 2005; see also Pollitt and Bouckaert 2004.
} 
are sub-contracted to the private sector, so the state begins to lose competence to do things which once it managed very well. ... Government becomes a kind of institutional idiot." (Crouch 2004, 41) Ironically, the results of NPM reforms are almost the exact opposite of what public choice theorists intended: instead of lowering socially costly rent-seeking, "the more that the state withdraws from providing for the lives of ordinary people, making them apathetic about politics, the more easily can corporate interests use it more or less unobserved as their private milch-cow." (Crouch 2004, 19) At the same time, there is strong evidence to suggest that developing countries profit from classical Weberian bureaucratic structures, in particular in terms of creating long-term administrative capacity as Weberian administration relies on strict legal principles (government actions are regulated by public law), and there is a strong emphasis on merit, competence and achievement in public service (entrance and promotion based on merit, competences and achievement) and clear hierarchies that enhance accountability. ${ }^{20}$ Weberian bureaucracy tends to focus on long-term strategic goals and thus provides especially developing countries with direly needed stability in policy planning and design. Indeed, the previous lack of strategic capacities in policy-making is perhaps the strongest reason why many developing countries should be particularly careful in experimenting with most recent administrative reform fashions like 'governing by networks'. (See also Schick 1998) However, we see also in developed European countries a growing trend towards what has been termed Neo-Weberian State, where notions of legality and accountability, competence and merit re-enter both the academic discourse and actual changes in public sector reforms. (Pollitt and Bouckaert 2004; Drechsler 2005).

It is, however, ironic but also deeply significant that in its core, the Washington Consensus and NPM go back to the same misreading of Adam Smith. We use here the term 'misreading' in a rather specific way. This term was coined in the late 1960s by Harold Bloom and denotes a process where authors creatively appropriate phrases, ideas from other authors in the writing process and mold them into something new or at any rate something different. Bloom, writing about theory of poetry, writes "Poetic history ... is ... indistinguishable from poetic influence, since strong poets make that history by misreading one another, so as to clear imaginative space for themselves." (Bloom 1997, 5) A misreading does not thus connote a negative meaning. Generalizing it into a hermeneutical principle, we can argue that a misreading is the way most theoretical works are read and written. We argue that the history of economic thought has one such key passage, namely the Smith's above-mentioned theorem about the size of the market

20 See in particular Evans and Rauch 1999, Rauch and Evans 2000, also Wade 2004. 
and the division of labor. The importance of the theorem can be easily understood from the famous example Smith himself uses, namely that of "the trade of the pin-maker". According to Smith, this particular occupation has gone through a transformation from a one-man business into at least 18 distinct operations performed by different individuals causing productivity per employee to increase from one pin a day to 4,800 pins a day. (Smith $1776 / 1976,1.1 .3)$ Such productivity explosions that follow innovations depend, as Smith rightly argued, on extensive trade and, as Smith also admitted, rapid technological development. While most researchers in economics and in related fields agree with the wide-brush description given by Smith, there are strongly varying misreadings about what causes and stimulates such innovations in the private sector. There are essentially two opposing schools of thought: On the one hand, there are scholars in the Schumpeterian/evolutionary/institutionalist tradition who argue that innovations and economic growth in general take place because of knowledge and skill agglomeration and continuous upgrading and technological change that are engendered by highly embedded policy-making of increasing coordination, dialogue and cooperation managed by highly capable state and administration. ${ }^{21}$ On the other hand, there are scholars in neo-classical and public choice traditions who argue that the main driver behind innovations and growth are trade and competition: the former using the comparative advantage of nations to bring more, better and cheaper goods to consumers (higher efficiency); the latter creating pressures for companies to incessantly innovate and outcompete the competitors, and to push prices downwards in the process (higher efficiency, again). ${ }^{22}$ While the differences in details are of course greater than described here, it is important to see that both traditions can be traced back to Adam Smith's theorem that the division of labor is limited by the size of the market (1776). The difference is how one understands the theorem: the former school takes it to mean that the division of labor is key (creation of knowledge and technological diversity, and the producer with his capabilities are the main policy goals), the latter school thinks the size of the market is key (the extent of trade and competition, and lower prices for consumers are the main policy goals).

If one, instead of accepting Adam Smith as an icon of free trade and laissez-faire under any circumstances, reads what he says about economic development at an early stage, one will find that he is very much in line with classical development economics, where industrialization is the key recommendation. In his early work, The Theory of Moral Sentiments (Smith

\footnotetext{
21 See on the role of the state and institutions in economic growth, e.g., Evans and Rauch 1999, Wade 2004 and Amsden 1989.

22 The most recent summary of such arguments is Rodrik 2007. For public choice, see most recently Buchanan and Yoon 2008
} 
1759/1810), Adam Smith argued passionately for "the great system of government", which is helped by adding new manufactures. Interestingly, Smith argued that new manufactures are to be promoted, neither to help suppliers nor to help consumers, but in order to improve this "great system of government".

In fact, it is possible to argue that Adam Smith was also a misunderstood mercantilist, someone who firmly supported the mercantilist policies of the past, but then argued that they were no longer necessary for England. He praises the Navigation Acts protecting English manufacturing and shipping against Holland, arguing "they are as wise ... as if they had all been dictated by the most deliberate wisdom" and holding them to be "perhaps, the wisest of all the commercial regulations of England" (Smith 1776/1976: I, 486-487). All in all, Smith described a development that had become successfully self-sustained, a kind of snowballing effect, originating in the wise protectionist measures of the past. Only once did Smith use the term 'invisible hand' in the Wealth of Nations: when it sustained the key import substitution goal of mercantilist policies, when the consumer preferred domestic industry to foreign industry (Smith 1776/1976: 477). This is when 'the market' had taken over the role previously played by protective measures, and national manufacturing no longer needed such protection. If one cared to look, Adam Smith also argued for tariff protection at an early stage as a mandatory passage point to development as did Friedrich List. Studying economic policy without discussing the context is one of the destructive vices of economic practice.

The key is not which side one chooses, however, but to see that both approaches are not simply complementary to each other but rather should be seen as following each other in a step-by-step development. This, indeed, is perhaps the greatest legacy of early development economists and Ragnar Nurkse: having synthesized these two broad theoretical schools into a coherent theoretical framework that proved highly successful once applied in real life.

\section{Conclusion: Where do we go from here?}

While the Fall of 2008 marks the end of the neo-liberal consensus about globalization and its rules in many ways, it is very much open to debate what direction economic and policy thinking will take from here on. Judging by history, a new development consensus will be in the making for the next decade. Following the classical development economists, what should be the cornerstones of the new consensus? 
As a reminder: we have argued above that the main development challenge left behind by the Washington Consensus and it affiliates is the difficulty in creating middle-income economies because of the loss of an activity-specific approach and of increasing returns-based economic policy making, and loss of how to generate the administrative capacity for development. In addition, the current techno-economic paradigm and financial globalization have enabled the decoupling of knowledge and production, and of production and finance. This has led to an international trade environment where developing countries are in effect engaged in beggar-thy-neighbor types of policies in order to capture increasing returns activities - and in which many of them do not succeed and end up in financially fragile development positions.

The key questions for further research and policy advice can be phrased as follows: how to couple trade, competition and similar policies with targeting increasing returns activities and how to create the financial environment where such activities (and their change) remain in hedged financing positions.

Here we can only demark three key areas where both theoretical and policy advances are necessary to start understanding how to achieve these goals; we argue these are areas where there is relatively little research currently done:

First, the geographical dimension has to be brought back into development economics as well as policy initiatives. While much of the world trade is in fact regional, there are few if any effective regional regulatory and policymaking regimes. Regional policy agenda is pivotal for trade and technology to exchange rate policies. (See also Wade 2008)

Second, in particular trade and competition policies (but also other areas, for instance, procurement) should concentrate on targeting increasing returns activities. There is, however, little research on how this can be done in a development context.

Third, the creation of the administrative capacity to implement policy reforms and in particular the capacity for targeting activities should be the focus of context-specific institutional reforms. While there is growing research on how highly developed countries recover from NPM reforms, there is very little research on developing countries. 


\section{References $^{23}$}

Amsden, Alice. 1989. Asia's Next Giant: South Korea and Late Industrialization. Oxford, England: Oxford University Press.

Amsden, Alice. 2007. Escape from Empire. The Developing World's Journey Through Heaven and Hell. Cambridge, MA / London: The MIT Press.

Arthur, W. Brian. 1994. Increasing Returns and Path Dependence in the Economy. Ann Arbor: University of Michigan Press

Balassa, Bela. 1971. "Trade Policies in Developing Countries." The American Economic Review, 61, 2, Papers and Proceedings of the Eighty-Third Annual Meeting of the American Economic Association. (May, 1971), 178-187.

Blecker, Robert A. 2000. "The Diminishing Returns to Export-led Growth." Available at http://www.cfr.org/content/publications/attachments/Blecker_Diminish_Paper.pdf. .

Bloom, Harold. 1997. The Anxiety of Influence. A Theory of Poetry, $2^{\text {nd }}$ edition. Oxford and New York: Oxford University Press.

Botero, Giovanni. 1588. Delle cause della grandezza delle città. Rome.

Buchanan, James M. and Yong J. Yoon. 2008. "Public Choice and the Extent of the Market." Kyklos, 61, 2, 177-188.

Chang, Ha-Joon. 2007. Bad Samaritans. Rich Nations, Poor Policies \& the Threat to the Developing World. London: Random House.

Cimoli, M., J. C. Ferraz, and A. Primi. 2005. Science and Technology Policies in Open Economies: The Case of Latin America and the Caribbean. Santiago: ECLAC.

Cimoli, Mario, Dosi, Giovanni, Nelson, Richard and Joseph Stiglitz. 2006. "Institutions and Policies Shaping Industrial Development: An Introductory Note." LEM Working Paper Series, 2/2006. Available at http://www.lem.sssup.it/WPLem/files/2006-02.pdf.

Clark, Gregory. 2007. A Farewell to Alms. A Brief Economic History of the World. Princeton: The Princeton University Press.

Collier, Paul. 2007. The Bottom Billion. Why the Poorest Countries Are Failing and What Can Be Done About It. Oxford: Oxford University Press.

Crouch, Colin. 2004. Post-Democracy. Cambridge: Polity.

Drechsler, Wolfgang. 2004. "Natural vs. Social Sciences: On Understanding in Economics". In Erik S. Reinert, ed., Globalization, Economic Development and Inequality. An Alternative Perspective, Cheltenham - Northampton, Mass.: Edward Elgar, 71-87.

Drechsler, Wolfgang. 2005. "The Rise and Demise of the New Public Management." post-autistic economics review, 33. Available at http://www.paecon.net/PAEReview/issue33/Drechsler33.htm. .

Easterly, William. 2008. "Can the West Save Africa?" NBER Working Paper

23 All websites accessed last in January 2009. 
Series, No 14363. Available at http://www.nber.org/papers/ w14363.pdf.

Evans, David and Parvin Alizadeh. 1984. "Trade, industrialisation, and the visible hand." Journal of Development Studies, 21, 1, 22-46.

Evans, Peter B. and James E. Rauch. 1999. "Bureaucracy and Growth: A Cross-National Analysis of the Effects of 'Weberian' State Structures on Economic Growth." American Sociological Review, $64,5,748-765$.

Galbraith, James K. 2008. "The Collapse of Monetarism and the Irrelevance of the New Monetary Consensus." The Levy Institute of Bard College, Policy Note 1/2008. Available at http://www.levy.org/ pubs/pn_08_1.pdf.

Gomory, Ralpk E. and William J. Baumol. 2004. "Globalization: Prospects, Promise and Problems." Journal of Policy Modeling, 26, 4, 425-438.

Hirschmann, Albert O. 1958. The Strategy of Economic Development. New Haven: Yale University Press.

Hirschmann, Albert O. 1984. "A Dissenter's Confession: 'The Strategy of Economic Development' Revisited." In Gerald M. Meier and Dudley

Seers, eds., Pioneers in Development. Oxford - New York: Oxford University Press, 87-111.

Huang, Yasheng. 2008. Capitalism with Chinese Characteristics. Entrepreneurship and the State. Cambridge: Cambridge University Press.

Johnson, Harry G. 1971. "The Keynesian Revolution and the Monetarist Counter-Revolution." The American Economic Review, 61, 2, Papers and Proceedings of the Eighty-Third Annual Meeting of the American Economic Association (May, 1971), 1-14.

Klein, Naomi. 2007. The Shock Doctrine. The Rise of Disaster Capitalism. New York: Metropolitan Books.

Kregel, Jan A. 2004. "External Financing for Development and International Financial Instability." G-24 Discussion Paper Series, United Nations. Available at http://www.unctad.org/en/docs/gdsmdpbg2420048 en.pdf.

Kregel, Jan A. 2008. "The Discrete Charm of the Washington Consensus". The Levy Economics Institute of Bard College Working Paper No 533. Available at http://www.levy.org/pubs/wp_533.pdf.

Krueger, Anne O. 2004. "Meant Well, Tried Little, Failed Much: Policy Reforms in Emerging Market Economies." Available at http://www. $\mathrm{imf}$.org/external/np/speeches/2004/032304a.htm.

Krugman, Paul. 1994. "The Fall and Rise of Development Economics." Available at http://web.mit.edu/krugman/www/dishpan.html.

Krugman, Paul. 2008. "Trade and Wages, Reconsidered." Available at http://www.princeton.edu/ pkrugman/pk-bpea-draft.pdf.

League of Nations. 1944. International Currency Experience. Lessons of the Inter-War Period. League of Nations.

Lynn Jr., Laurence E. 2001. “The Myth of the Bureaucratic Paradigm: What 
Traditional Public Administration Really Stood For." Public Administration Review, 61, 2, 144-160.

Madisson, Angus. 2003. The World Economy. Historical Statistics. Paris: OECD.

Meier, Gerald M. and Dudley Seers, eds. 1984. Pioneers in Development. Oxford - New York: Oxford University Press.

Nurkse, Ragnar. 1953. Problems of Capital Formation in Underdeveloped Countries. Oxford: Oxford University Press.

Nurkse, Ragnar. 1961. Equilibrium and Growth in the World Economy. Gottfried Haberler and Robert M. Stern, eds. Harvard Economic Studies CXVIII. Cambridge, MA: Harvard University Press.

North, Douglass, Wallis, John and Barry Weingast. 2008. "Violence and Social Orders: A Conceptual Framework for Interpreting Recorded Human History." In Governance, Growth, and Development Decision-Making. Washington; World Bank. Available at http://siteresources.worldbank.org/EXTPUBLICSECTORANDGOVERNANCE/Resources/governanceandgrowth.pdf.

Palley, Thomas. 2006. Rethinking Trade and Trade Policy. Gomory, Baumol, and Samuelson on Comparative Advantage. The Levy Economics Institute of Bard College, No 86.

Palma, Gabriel. 2005. "The Seven Main 'Stylized Facts' of the Mexican Economy Since Trade Liberalization and NAFTA," Industrial and Corporate Change 14 (6): 941-991.

Perez, Carlota. 2002. Technological Revolutions and Financial Capital: The Dynamics of Bubbles and Golden Ages. Cheltenham: Elgar.

Perez, Carlota. 2006. "Respecialisation and the Deployment of the ICT Paradigm: An Essay on the Present Challenges of Globalization". In

R. Compañó, C. Pascu, A. Bianchi, J-C. Burgelman, S. Barrios, M. Ulbrich, I. Maghiros (eds.), The Future of the Information Society in Europe: Contributions to the Debate. Seville, Spain: European Commission, Directorate General Joint Research Centre.

Pollitt, Christopher and Geert Bouckaert. 2004. Public Management Reform. A Comparative Analysis. 2 ed. Oxford: Oxford University Press.

President's Commission on Industrial Competitiveness. 1985. Global Competition. The New Reality. The Report of the President's Commission on Industrial Competitiveness, volume 1.

Rauch, James E. and Peter B. Evans. 2000. "Bureaucratic structure and bureaucratic performance in less developed countries." Journal of Public Economics, 75, 49-71.

Reinert, Erik S. 1980. International Trade and the Economic Mechanisms of Underdevelopment. Cornell University, University Microfilms.

Reinert, Erik S. 2007. How Rich Countries Got Rich ... and Why Poor Countries Stay Poor. London: Constable.

Reinert, Erik S., Yves Ekoué Amaïzo and Rainer Kattel. 2008. “The Economics of Failed, Failing and Fragile States: Productive Structure as the Missing Link." The Other Canon and Tallinn University of 
Technology Working Papers in Technology Governance and Economic Dynamics. Forthcoming.

Reinert, Erik S. and Rainer Kattel. 2007. "European Eastern enlargement as Europe's attempted economic suicide?" The Other Canon and Tallinn University of Technology Working Papers in Technology Governance and Economic Dynamics, no. 14. Available at http://tg.deca.ee/files/main//2007070309122525.pdf.

Rodrik, Dani. 2006. “Goodbye Washington Consensus, Hello Washington Confusion? A Review of the World Bank's Economic Growth in the 1990s: Learning from a Decade of Reform." Journal of Economic Literature, XLIV, 973-987.

Rodrik, Dani. 2007. One Economics, Many Recipes. Globalization, Institutions, and Economic Growth. Princeton and Oxford: Princeton University Press.

Rodrik, Dani. 2008. "Thinking about governance." In Governance, Growth, and Development Decision-Making. Washington; World Bank. Available at http://siteresources.worldbank.org/EXTPUBLICSECTORANDGOVERNANCE/Resources/governanceandgrowth.pdf.

Rosentsein-Rodan, Paul N. 1984. "Natura Facit Saltum: Analysis of the Disequilibrium Growth Process."In Gerald M. Meier and Dudley Seers, eds., Pioneers in Development. Oxford - New York: Oxford University Press, 207-221.

Sachs, Jeffrey. 2004. The End of Poverty. How Can We Make It Happen In Our Lifetime. New York: The Penguin Press.

Sachs, Jeffrey. 2008. Common Wealth. Economics for a Crowded Planet. New York: The Penguin Press.

Samuelson, Paul. 2004. "Where Ricardo and Mill Rebut and Confirm Arguments of Mainstream Economists Supporting Globalization." Journal of Economic Perspectives, 18, 3, 2004, 135-146.

Schick, Allen. 1998. "Why Most Developing Countries Should Not Try New Zealand's Reforms." World Bank Research Observer, 13, 123-131.

Schleifer, Andrei. 2008. "The Age of Milton Friedman." Available at http://www.economics.harvard.edu/faculty/shleifer/files/friedman3.3.pdf.

Schmoller, Gustav von. 1881 (1893-4). The Idea of Justice in Political Economy, Annals of the American Academy of Political and Social Science, 4, 697-737.

Scott, Bruce and George C. Lodge, eds. 1985. US Competitiveness in the World Economy. Boston, MA: Harvard Business School Press.

Skidelsky, Robert. 2008. "Gloomy about Globalization". New York Review of Books, 55, 6, April 17. Available at http://www.nybooks.com/ articles/21259.

Smith, Adam. 1776/1976. An Inquiry into the Nature and Causes of the Wealth of Nations. London: Methuen and Co. Available at http://www.econlib.org/LIBRARY/Smith/smWN.html. 
Smith, Adam. 1759/1810. The Theory of Moral Sentiments. London: A. Millar. Sombart, Werner. 1949. "Sociology: What It Is and What It Ought to be an. Outline for a Noo-Sociology". The American Journal of Sociology, 55, 2, 178-193.

Stigler, George J. 1951. "The Division of Labor is Limited by the Extent of the Market." Journal of Political Economy, 59, 185-193.

Summers, Lawrence. 2008. "A strategy to promote healthy globalization". Financial Times, May 4. Available at http://www.ft.com/cms/s/0/ 999160e6-1a03-11dd-ba02-0000779fd2ac.html?nclick check $=1$.

Tocqueville, Alexis de. 1876. Democracy in America. 2 vols. $6^{\text {th }}$ ed. Boston: John Allyn.

Toye, John. 1987. Dilemmas of Development. Reflections on the CounterRevolution in Development Theory and Policy. Oxford: Blackwell.

Tiits, Marek, Rainer Kattel, Tarmo Kalvet and Dorel Tamm. 2008. “Catching up, pressing forward or falling behind? Central and Eastern European development in 1990-2005." The European Journal of Social Science Research, 21, 1, March, 65-85.

Urban, Scott. 2009. "International Currency Experience and the Bretton Woods System: Ragnar Nurkse as Architect." In this volume.

Viner, Jacob. 1937. Studies in the Theory of International Trade. Clifton, $\mathrm{NJ}$ : Kelly.

Wade, Robert. 2004. Governing the Market: Economic Theory and the Role of Government in East Asian Industrialization, $2^{\text {nd }}$ edition. Princeton: Princeton University Press.

Wade, Robert. 2008. "Financial Regime Change?" New Left Review, 53, September-October. Available at www.newleftreview.org.

Williamson, John. 2002. "What Washington Means by Policy Reform." Available at http://www.iie.com/publications/papers/paper.cfm? ResearchID $=486$. (Updated version of his 1990article.)

Williamson, John. 2008. "Williamson versus the Washington Consensus?" Available at http://www.growthcommissionblog.org/content/ williamson-versus-the-washington-consensus.

World Bank. 2006. Economic Growth in the 1990s: Learning from a Decade of Reform. Available at http://www1.worldbank.org/prem/ lessons1990s/.

World Bank. 2008a. The Growth Report: Strategies for Sustained Growth and Inclusive Development. Available at http://www.growthcommission.org/index.php?option $=$ com_content $\&$ task $=$ view\&id $=96 \&$ Itemid $=169$.

World Bank. 2008b. Science, Technology, and Innovation. Capacity Building for Sustainable Growth and Poverty Reduction. Available at http://go.worldbank.org/GEYA2NRGWO.

Young, Allyn. 1928. "Increasing Returns and Economic Progress." The Economic Journal, 38, 527-542. 


\section{Working Papers in Technology Governance and Economic Dynamics}

The Other Canon Foundation, Norway, and the Technology Governance program at Tallinn University of Technology (TUT), Estonia, have launched a new working papers series, entitled "Working Papers in Technology Governance and Economic Dynamics". In the context denoted by the title series, it will publish original research papers, both practical and theoretical, both narrative and analytical, in the area denoted by such concepts as uneven economic growth, techno-economic paradigms, the history and theory of economic policy, innovation strategies, and the public management of innovation, but also generally in the wider fields of industrial policy, development, technology, institutions, finance, public policy, and economic and financial history and theory.

The idea is to offer a venue for quickly presenting interesting papers scholarly articles, especially as preprints, lectures, essays in a form that may be developed further later on - in a high-quality, nicely formatted version, free of charge: all working papers are downloadable for free from http://hum.ttu.ee/tg as soon as they appear, and you may also order a free subscription by e-mail attachment directly from the same website.

The first nine working papers are already available from the website.

They are

1. Erik S. Reinert, Evolutionary Economics, Classical Development Economics, and the History of Economic Policy: A Plea for Theorizing by Inclusion.

2. Richard R. Nelson, Economic Development from the Perspective of Evolutionary Economic Theory.

3. Erik S. Reinert, Development and Social Goals: Balancing Aid and Development to Prevent 'Welfare Colonialism'.

4. Jan Kregel and Leonardo Burlamaqui, Finance, Competition, Instability, and Development Microfoundations and Financial Scaffolding of the Economy.

5. Erik S. Reinert, European Integration, Innovations and Uneven Economic Growth: Challenges and Problems of EU 2005.

6. Leonardo Burlamaqui, How Should Competition Policies and Intellectual Property Issues Interact in a Globalised World?

A Schumpeterian Perspective

7. Paolo Crestanello and Giuseppe Tattara, Connections and Competences in the Governance of the Value Chain. How Industrial Countries Keep their Competitive Power 
8. Sophus A. Reinert, Darwin and the Body Politic: Schäffle, Veblen, and the Shift of Biological Metaphor in Economics

9. Antonio Serra, Breve Trattato / A Short Treatise (1613) (available only in hardcopy and by request).

10. Joseph L. Love, The Latin American Contribution to CenterPeriphery Perspectives: History and Prospect

11. Ronald Dore, Shareholder capitalism comes to Japan

12. Per Högselius, Learning to Destroy. Case studies of creative destruction management in the new Europe

13. Gabriel Yoguel, Analía Erbes, Verónica Robert, and José Borello, Diffusion and appropriation of knowledge in different organizational structures

14. Erik S. Reinert and Rainer Kattel, European Eastern Enlargement as Europe's Attempted Economic Suicide?

15. Carlota Perez, Great Surges of development and alternative forms of globalization

16. Erik S. Reinert, lulie Aslaksen, Inger Marie G. Eira, Svein Mathiesen, Hugo Reinert \& Ellen Inga Turi, Adapting to Climate Change in Reindeer Herding: The Nation-State as Problem and Solution

17. Lawrence King, Patrick Hamm, The Governance Grenade: Mass Privatization, State Capacity and Economic Development in Postcommunist and Reforming Communist Societies

18. Reinert, Erik S., Yves Ekoué Amaïzo and Rainer Kattel. The Economics of Failed, Failing and Fragile States: Productive Structure as the Missing Link

19. Carlota Perez. The New Technologies: An Integrated View

20. Carlota Perez, Technological revolutions and techno-economic paradigms

21. Rainer Kattel, Jan A. Kregel, Erik S. Reinert, The Relevance of Ragnar Nurkse and Classical Development Economics

The working paper series is edited by Rainer Kattel (kattel@staff.ttu.ee), Wolfgang Drechsler (drechsler@staff.ttu.ee), and Erik S. Reinert (reinert@staff.ttu.ee), who all of them will be happy to receive submissions, suggestions or referrals. 